International Journal of Environmental, Sustainability, and Social Sciences

ISSN 2720-9644 (print); ISSN 2721-0871 (online)

https://journalkeberlanjutan.com/index.php/ijesss

Volume: 2

Number: 2

Page: $117-126$

\section{Article History:}

Received: 2021-06-16

Revised: 2021-07-10

Accepted: 2021-07-26

\title{
FACTORS AFFECTING DYSFUNCTIONAL AUDIT BEHAVIOR
}

\section{Afly YESSIE}

Faculty of Economics and Business University of Mercu Buana, Indonesia

Corresponding author: Afly YESSIE

Faculty of Economics and Business University of Mercu Buana, Indonesia

Email: afly.yessie@gmail.com

\begin{abstract}
:
This study aims to test influence of turnover intention, performance auditor, organizational commitment, locus of control, Times budget pressure and professional commitment on dysfunctional audit behavior. This research was conducted on auditors in Jakarta, so that total samples were 53 auditors. The results of this study indicate turnover intention, performance audit, time budget pressure and professional commitment have a positive and significant effect on the dysfunctional audit behavior while the locus of control and organizational commitment negatively affect the dysfunctional audit behavior. This research contributes to develop science, especially in the field of auditing the acceptance of dysfunctional audit behavior. The results of this study are also expected to be used by public accounting firms to consider when to hire new auditors so that companies prefer those who have a high locus of control and have a high organizational commitment so that acceptance of dysfunctional audit behavior can be minimized.
\end{abstract}

\section{Keywords:}

Dysfunctional audit behaviour, Public Accounting Firm

Cite this as: YESSIE, A. (2021). "Factors Affecting Dysfunctional Audit Behavior." International Journal of Environmental, Sustainability, and Social Sciences, 2 (2), 117-126. https://doi.org/10.38142/ijesss.v2i2.84

\section{INTRODUCTION}

Financial statements are a must-have for an entity or company. The financial statements are presented as information for investors and are used as a basis for consideration and decisions. The presentation of financial statements can be said to be reasonable and reliable if it has implemented the accounting standards that have been set in the financial accounting standards (SAK) in its reports. Pujaningrum, et al (2012:1) in disclosing the fairness and reliability of a financial statement, the user needs a third party i.e. a public accountant to disclose whether the report has met accounting standards in its presentation. Auditors are required to carry out their work professionally so that the resulting audit report will be qualified. The quality of the auditor's work relates to the quality of expertise, timeliness of completion of the work, the adequacy of the proof of examination, and the attitude of independence towards the client. Audit quality is defined as the probability that an auditor can determine and report misconduct that occurs in the client's accounting system.

Auditors have a role that is no less important in shaping the trust of users of financial reporting information. Research conducted by J. Svanberg and P. Ohman, 
that identifies widespread unethical behavior in commercial organizations (Captein, 2011). In public accounting firms, a large number of unethical behaviors have been dismissed as time-pressure effects (Coram et al, 2003; Otley and Pierce, 1996a,; Pierce, 2004). Time budget pressure (TBP) has been observed to increase underreporting of time (URT) and frequency of a series of dysfunctional auditor behaviors called reduced audit quality action (RAQ acts). Limitations in research are recognized when interpreting the results. One limitation arises from the fact that respondents as a large occupied high positions in KAP, making the results less generalisable. Chairunnisa, et al. (2014:2) states that the professional behavior of public accountants is one of them manifested in the form of avoiding deviant behavior in audit (dysfunctional audit behavior). Dysfunctional behavior of the auditor in question is deviant behavior conducted by the auditor by carrying out the audit process that is not in accordance with the audit procedures that have been established and the applicable standards. This behavior can affect the quality of audits either directly or indirectly. Turnover intention is the attitude of a member of an organization to resign from an organization or in this case, from the Public Accounting Firm as an independent auditor. Employee withdrawal in the form of turnover has become an interesting research material in various issues, such as personnel problems (HR), behavior, and management practitioners. Turnover intention is also influenced by skill and ability, where the lack of auditor's ability can reduce the desire to leave the organization so that he remains in kap even though he is eager to change jobs (Desi et al, 2014).

Performance auditors are also another factor influencing dysfunctional audit behavior. Performance is basically a result of work achieved by an employee in quality and quantity in carrying out his duties in accordance with the responsibilities given to him. An employee who is underperforming is likely to receive dysfunctional behavior. Because an employee will do anything to show that his performance is relatively high. Commitment Organizational (organization commitment), Dewa Gede, et al (2015) explained that a high level of organizational commitment will be associated with the elimination of behavior in the audit, this is done with the aim of maintaining the organization in which they work. Violation of accounting and audit standards at PT Tiga Pilar Sejahtera Food, Tbk (AISA). KAP and auditors who conducted an examination of the financial statements in the period 2017, namely Didik Wahyudi one of RSM Indonesia's Partners. From the results of the investigation there are findings on the alleged inflated accounting post worth Rp 4 trillion as well as several other allegations. The Ministry of Finance sees indications of violations from AISA auditors in the form of sanctions on KAP and public accountants (AP). The lightest sanctions from warnings to freezing of professional practice permits. Administrative sanctions were imposed on public accountants (AP) responsible for opinions given to the financial statements of SNP Finance (2018), PT. Three Pillars of Indonesia (2017), and PT. Garuda Indonesia (2019). The administrative sanctions were imposed because the public accountant (AP) had violated the administrative provisions of its audit of each company's annual financial statements. Violation of administrative provisions or not implementing existing audit standards is the deviant behavior of auditors or dysfunctional audit behavior. Looking at the above cases, the auditor's deviant behavior has led to the user's distrust of financial statements against the opinions given by the auditor. Therefore, practitioners and researchers in the field of accounting seek to improve their performance and strive to restore the trust of users of financial statements over the profession of auditors. Ratna, et al (2013) one of the factors influencing the auditor's dysfunctional behavior is the Locus of Control. The concept of Locus of Control is used to explain differences in individual behavior in organizational settings. The locus of individual control reflects a person's level of confidence in the extent to which their behavior or actions affect their success 
or failure. Time budget pressure is a condition that indicates that auditors are required to make efficiency to the set time budget or there are time restrictions in the budget that tend to be tight and rigid (Lendi \& Dani, 2017). According to the results of research conducted by (Dewi \& Wirasedana, 2015; Sari, Tenriwaru, 2016; Felinda 2018) that time budget pressures have a positive and significant effect on dysfunctional auditor behavior. This is in line with research conducted by Dewi and I D.G Dharma, (2019) that time budget pressure positively affects the dysfunctional behavior of auditors. Professional commitment can be interpreted as an individual characteristic related to his loyalty to the goals and values of his profession (lobo, 2017). If the auditor with a high professional commitment then they like the profession, and give loyalty and dedication in the profession that he undergoes so as to be far from behavior that can potentially damage a profession. Meanwhile, auditors with lower professional commitments are more likely to do the opposite and are likely to behave dysfunctionally. According to mangiwa et al research, (2020) stated that professional commitment positively affects the dysfunctional behavior of auditors, this is in line with the results of research conducted by Lobo, (2017) using analysis techniques is multiple regression analysis, stating that professional commitment partially negatively and significantly affects dysfunctional audit behavior. According formulation of the problem, the purpose of this research is:

a) To analyze the effect of turnover intention on dysfunctional audit behavior.

b) To analyze the effect of performance auditor on dysfunctional audit behavior.

c) To analyze the influence of organizational commitment on dysfunctional audit behavior.

d) To analyze the influence of locus of control on dysfunctional audit behavior.

e) To analyze the influence of time budget pressure on dysfunctional audit behavior.

f) To analyze the influence of professional commitment on dysfunctional audit behavior.

The results of this study are expected to be useful for the Public Accounting Firm and provide empirical evidence on whether or not there is an influence between variable turnover intention, performance auditor, organizational commitment, locus of control, budgetary pressure and professional commitment on dysfunctional auditor behavior. And provide input for the Public Accounting Firm to evaluate policies that can be done to overcome the possibility of auditor irregularities in the audit process. The results of this study are expected to be used as a reference and additional knowledge about the relationship between turnover intention, performance auditor, organizational commitment, locus of control, time budget pressure and professional commitment on dysfunctional auditor behavior in the future.

The desire to leave the organization is functional, if the employee who leaves the organization is an employee who is considered eligible to leave. This opens up opportunities for people who are motivated or more capable, opens up opportunities for promotion, and opens up new and fresh ideas for the organization. The desire to leave the organization is dysfunctional, if the employee who leaves the company is a highly capable employee. Dewa Gede Agung Basudewa\&Ni Kt. Lely Aryani Merkusiwati (2015) examined the influence of Locus of Control, Organizational Commitment, Auditor Performance, and Turnover Intention. Research of (Anita, Anugerah \& Zulbahridar 2016; Basudewa \& Merkusiwati 2015; Pujaningrum \& Sabeni 2012; Kusumawati 2018; Chairunnisa, Zulbahridar, Rahmiati 2014) proves that turnover intention has an influence on dysfunctional audit behavior. (Agus, et al 2011; Ratna, et al 2017) rejected the statement because young auditors tend to still have a high level of idealism.

H1. Turn over Intention positive effect on Dysfunctional Auditor Behavior. 


\section{International Journal of Environmental, Sustainability, and Social Sciences ISSN 2720-9644 (print); ISSN 2721-0871 (online) \\ https://journalkeberlanjutan.com/index.php/ijesss}

Dysfunctional behavior can occur in situations when an individual feels himself or herself unable to achieve the expected results through his or her own efforts. Donelly et al. (2003) states that individuals who perform substandardly are highly likely to engage in dysfunctional behavior because they consider themselves to lack the ability to survive in the organization through their own efforts. In the research of Rizqa Anita, Rita Anugerah \&Zulbahridar (2016), Ratna Prasetyoningrum Evanauli, Ietje Nazaruddin (2013), Agus Wahyudin, Indah Anisykurillah, Dwi Harini (2011) stated that auditor performance negatively affects the dysfunctional behavior of auditors. However, in the research of Dewa Gede Agung Basudewa \&Ni Kt. Lely Aryani Merkusiwati (2015), Intan Pujaningrum \&Arifin Sabeni (2012), Ida Kusumawati (2018), Desi Chairunnisa, Zulbahridar, Rahmiati (2014) stated that auditor performance affects the dysfunctional behavior of auditors.

H2. Performance Auditor negative effect on Dysfunctional Auditor Behavior.

Organizational Commitment is an organizational commitment defined as a situation where an employee favors a particular organization and its goals and desires to maintain membership in that organization. thus, high job engagement means favoring an individual's particular job, while high organizational commitment means favoring the organization that recruits that individual. Research conducted by Dewa Gede Agung Basudewa \&Ni Kt. Lely Aryani Merkusiwati (2015), Muslim Alkautsar (2014), proves that organizational commitment affects the acceptance of dysfunctional audit behavior. The higher an employee favors the organization that recruits him or her, the more likely the individual will be to receive dysfunctional audit behavior.

H3. Organizational Commitment negative effect on Dysfunctional Auditor Behavior.

Individuals with external locus of control assume the results or outcomes obtained are not derived from their efforts, but derived from situational factors such as environment and luck or miracles. Individuals with this kind of character need to be pushed harder in order to work well to meet predetermined targets and are usually reactive. Research conducted by Rizqa Anita, Rita Anugerah \&Zulbahridar (2016), Agus Wahyudin, Indah Anisykurillah \&Dwi Harini (2011), Ratna Prasetyoningrum Evanauli \&Ietje Nazaruddin (2013), Ida Perawati \&Sutapa (2016) proved that locus of control affects dysfunctional audit behavior. Individuals who have locus of control allow to receive dysfunctional audit behavior.

H4. Locus of Control negative effect on Dysfunctional Auditor Behavior.

Auditors do their job with a time budget that is measured to the maximum and in accordance with its capabilities, then the auditor will complete the task well without pressure, but if the auditor works under pressure it will affect the performance of the auditor itself. The higher the time of budget pressure experienced by auditors, the higher the acceptance of deviant behavior as well. Rhode Research (1978); Aldermen and Deitrick (1982), Kelley and Seiler (1982), Lightner et al (1982), Margheim and Pany (1986), Cook and Kelley (1982), Kelley and Margheim (1990). A theoretical workstress model to investigate the impact of time budget pressures and some personality variables on dysfunctional audit behavior.

H5. Time Budget Pressures negative effect on Dysfunctional Auditor Behavior.

Professional commitment can be interpreted as an individual characteristic related to his loyalty to his professional goals and values (lobo, 2017). If the auditor with high professional commitment then they like the profession, and give loyalty and dedication in the profession that he undergoes so as to be far from behavior that can 
International Journal of Environmental, Sustainability, and Social Sciences

ISSN 2720-9644 (print); ISSN 2721-0871 (online)

https://journalkeberlanjutan.com/index.php/ijesss

potentially damage a profession. Meanwhile auditors with lower professional commitments will tend to do the opposite and are likely to behave dysfunctionally.

H6. Professional Commitment positive effect on Dysfunctional Auditor Behavior.

\section{METHODS}

This study uses causal research method with associative hypothesis that aims to test the influence of one or more variables on certain variables that are causal, between a variable (Independent/Xn) and another variable (Dependent Variable/Yn). Variables used in this study are dependent variables, namely dysfunctional Auditor behavior and independent variables, namely turnover intention, performance auditor, organizational commitment, locus of control, budgetary pressure and professional commitment. This research requires hypothesis testing with statistical tests. Population understanding according to Sugiyono (2016:80) is a generalized area consisting of objects/subjects that have certain qualities and characteristics set by researchers to be studied and then drawn conclusions. The population used in this study is auditors working at the Public Accounting Firm (KAP) in the DKI Jakarta area who were registered with the Indonesian Institute of Public Accountants (IAPI) in 2019. Based on information obtained from the Indonesian Institute of Public Accountants (IAPI), the number of Public Accounting Firms (KAP) located in the DKI Jakarta area is as much as $286 \mathrm{KAP}$ and the number of Public Accounting Firms (KAP) that are willing to receive questionnaires is $40 \mathrm{KAP}$, as many as $246 \mathrm{KAP}$ are not willing to receive questionnaires because it coincides with the kap pick season. The infinite method is used because of the sampling of sample members from the population. Infinite population is a population that maximizes the process continuously so that the size of $\mathrm{N}$ becomes unlimited changes in value (Suharyadi, 2015:7) Respondents used in this study are partners, managers, senior auditors, supervisors and junior auditors working at the Public Accounting Firm in DKI Jakarta.

\section{RESULT AND DISCUSSION}

This study tested the influence of Turnover Intention, Performance Auditor, Organizational Commitment, Locus of Control, Time Budget Pressure, and Professional Commitment on Dysfunctional Auditor Behavior at the Public Accounting Firm of DKI Jakarta. Based on test results $t$ by comparing the values of $t-$ value and t-table. The hypothesis is accepted if $t$-value $>t$-table or sig $<0,05$. It can be seen that significant research variables turnover Intention as large as 0,042. Thus, it can be said that the significant value of $0,042<0,05$ and result $t$-value $2,059>t-$ table.1,979. Turnover Intention significant effect on Dysfunctional Auditor Behavior at KAP DKI Jakarta. Turnover Intention indicates where the auditor has the curiosity to switch jobs. Auditors with a high desire to move work will tend to be less concerned with what it does for the organization though and if a decrease in the auditor's fear of being sanctioned for dysfunctional behavior is detected. If the competition for work is very high and the number of jobs is minimal, auditors will rethink to conduct dysfunctional behavior because auditors will have a high potential to lose their jobs and fixed income, even though the auditor has not yet got a new job. Thus, it can be explained the relationship between turnover intention and dysfunctional behavior of auditors if an auditor has a great sense of responsibility to the work being pursued, it will not affect dysfunctional behavior and although turnover intention exists, the auditor has a strong commitment to the code of ethics of auditors or public accountants. Thus, despite the turnover intention auditors persist with their professional commitment and avoid audit dysfunctional behavior. This research is in line with research conducted by Ratna (2017), which states turnover intention positively affects dysfunctional audit behavior. Individuals have a 
high level of idealism towards their work as an auditor, so that the auditor will do the tasks that are his responsibility as best as possible and perform the tasks in accordance with the procedure.

Based on test results $t$ by comparing the values of tvalue and ttable.. The hypothesis is accepted if tvalue $>$ ttable or sig $<0,05$. It can be seen that significant research variables performance auditor as large as 0,002. Thus it can be said that the significant value of $0,002<0,05$ and result tvalue 3,200 $>$ ttable .1,979. Performance auditor significant effect on Dysfunctional Auditor Behavior at KAP DKI Jakarta. Performance Auditor shows the performance of the auditor or performance that has been achieved by an auditor for his efforts in carrying out the tasks that have been charged to him in accordance with his own responsibilities. the performance of the auditors does not affect the acceptance of dysfunctional behavior of auditor behavior because an individual will put forward his commitment to the organization so that the achievements that the auditor has will not affect the dysfunctional audit behavior. Thus, it can be explained that there is an influence between performance audit and dysfunctional behavior of auditors. The results of this study are different from other studies because it has many limitations that this research is conducted in different places, different years, and different samples with previous research.

Based on test results $t$ by comparing the values of $t$-value and $t$-table.. The hypothesis is rejected if t-value $<t$-table or sig $>0,05$. It can be seen that significant research variables organizational commitment as large as 0,292 . Thus it can be said that the significant value of $0,292>0,05$ and result $t$-value $1,058<\mathrm{t}$-table..1,979. Organizational commitment significant effect on Dysfunctional Auditor Behavior at KAP DKI Jakarta. Organizational commitment is also called work commitment, reflecting the identification and bond of an individual to the organization. A very committed person will probably see himself as a true member of a company, ignore the source of minor dissatisfaction, and see himself remain a member of the organization. On the contrary, a less committed person is more likely to see himself or herself as an outsider, express more dissatisfaction about many things, and not see himself as a long-term member of the organization. But this research shows that commitment to organization has a positive influence on dysfunctional audit behavior. Which means that the auditor who works in KAP DKI Jakarta area, the more he has a commitment to his organization, the more likely it is to receive dysfunctional audit behavior. This research is not in line with previous research due to different research places, different years and different sample counts. So it can be concluded that an auditor will do anything to be able to survive on his organization. So auditors have the possibility to conduct dysfunctional behavior in order for their organization to survive even though an auditor must do things that violate audit standards.

Based on test results $t$ by comparing the values of tvalue and ttable.. The hypothesis is rejected if tvalue $<$ ttable or sig $>0,05$. It can be seen that significant research variables locus of control as large as 0,480 . Thus it can be said that the significant value of $0,480>0,05$ and result tvalue $0,708>$ ttable..1,979. Locus of Control significant effect on Dysfunctional Auditor Behavior at KAP DKI Jakarta. This means that the more a person feels that the achievements obtained are not from himself or herself, the more dysfunctional the audit behavior will be. Individuals with external locus of control assume the results or outcomes obtained are not derived from their efforts, but derived from situational factors such as environment and luck or miracles. Individuals with this kind of character need to be pushed harder in order to work well to meet predetermined targets and are usually reactive. Thus, it can be explained the relationship between locus of control and dysfunctional audit behavior when an individual feels unable to get the strength support he or she needs to survive in an organization, they have the potential to try to manipulate colleagues or other objects as their defense needs in an organization. This is the next thing that leads to 
dysfunctional behavior. This research is consistent with research conducted by (Anita, Rita \& Zulbahridar (2016); (Agus Wahyudin, Anisykurillah \& Harini 2011; Evanauli \& Nazaruddin (2013); Perawati \& Sutapa 2016) proving that locus of control affects dysfunctional audit behavior. And states that individuals who have locus of control allow to receive dysfunctional audit behavior.

Based on test results $t$ by comparing the values of tvalue and ttable.. The hypothesis is rejected if tvalue $<t$-table or sig $>0,05$. It can be seen that significant research variables time budget pressure as large as 0,618 . Thus it can be said that the significant value of $0,618>0,05$ and result tvalue $-0,500>t$-table.1,979. Time budget pressure significant effect on Dysfunctional Auditor Behavior at KAP DKI Jakarta. Timely completion of audits in addition to meeting client requests is also one of the keys to a successful auditor's future career. Therefore, there is always pressure for auditors to complete audits within the budgeted time. Audit time budget pressure is actually a normal situation in the auditor's work environment (Sari et al., 2016: 8). According to Margheim et al, (2005: 24) explains that "Budget-related time pressures can only occur when the budgeted amount of time is less than the total time available and auditors have the ability to respond to pressure by completing work on their personal time and not reporting the amount of time spent on audit tasks". Budget audit time is one of the main factors that determine the success of auditors in carrying out audit assignments. Hardyan (2013: 19) explains that "audit time budgets are also a benchmark in the evaluation of auditor staff, each auditor has a budget time target that must be met and if there is an overtime budget then the evaluation of the auditor is negative, when faced with budgetary pressures of time, the auditor will respond in two ways: functional response and dysfunctional response.

Based on test results $t$ by comparing the values of $t$-value and t-table.. The hypothesis is rejected if $t$-value $<t$-table or sig $>0,05$. It can be seen that significant research variables time professional commitment as large as 0,186 . Thus it can be said that the significant value of $0,186>0,05$ and result $t$-value 1,331>t-table.1,979. Professional Commitment significant effect on Dysfunctional Auditor Behavior at KAP DKI Jakarta. Commitment has become one of the important elements in the world of work. One of the factors that can affect a person's success and performance in the job is commitment. The underlying reason for the need for a high commitment to each profession is the need for public trust in the quality of services provided by the profession regardless of what is done individually. Understanding this professional commitment is very important in order to create conducive working conditions so that the company can run efficiently and effectively (Damanik, 2015: 66-67). Public trust in the quality of professional services will increase, if the profession realizes high standards of work and behavior and meets all needs.

\section{CONCLUSION}

Based on the results of the analysis and discussion of research, it can be concluded as follows:

(1) Turnover Intention affects dysfunctional auditor behavior, this means that the auditor's desire to switch jobs has a very strong reason while maintaining a professional attitude. (2) Performance auditors affect dysfunctional auditor behavior, this indicates that the auditor has not achieved what the company wants. (3) Organizational commitment has no effect on dysfunctional auditor behavior, indicating the low commitment of auditors to the company, so inclined will not stay long in the company. (4) Locus of control has no effect on dysfunctional auditor behavior, this indicates that auditors inclined behave deviantly to attract attention to its capabilities. (5) Time Budget Pressure has no effect on dysfunctional auditor behavior, this indicates that auditors in completing work are limited by the time of examination. (6) Professional commitment has no effect on dysfunctional auditor 


\section{International Journal of Environmental, Sustainability, and Social Sciences ISSN 2720-9644 (print); ISSN 2721-0871 (online) \\ https://journalkeberlanjutan.com/index.php/ijesss}

behavior, this indicates that auditors need clarity of commitment to improve their performance.

The days of the future, this research is expected to present the results of better quality with some suggestions as follows: (1) For further research, should not be distributing questionnaires month of December to February, because at that time the auditors are in the populous working period (high season). (2) Research is then expected to expand the sample areas or regions questionnaires. (3) Research can then add variables associated with the detection of fraud, such as time pressure, education, expertise auditors and other independent variables.

\section{REFERENCES}

Alkautsar, M. (2014). Locus of control, commitment profesional and dysfunctional audit behaviour. International Journal of Humanities and Management Sciences (IJHMS), 2(1), 35-38.

Alderman, C.W. and Deitrick, J.W. (1982) 'Auditors' perceptions of time budget pressures and premature sign-offs: a replication and extension', Auditing: AJournal of Practice and Theory, Vol. 1, No. 2, pp.54-68.

Anita, R., Anugerah, R., \& Zulbahridar. (2005). Auditor acceptance analysis on dysfunctional audit behavior: auditor's personal characteristics approach (Empirical Study on Public Accounting Firm in Java). Max, 5(June).

Asmara, Chandra Gian. (2019, April 5). Chaos AISA, Ministry of Finance: There are Indications of Violation of the RSM Auditor. Accessed July 19, 2019: https: / /www.cnbcindonesia.com/market/20190405115007-17-64845/kisruhaisa-kemenkeu-ada-indication-pelaksanaan-auditor-rsm

Asmara, Chandra Gian. (2019, April 5). Chaos AISA, Ministry of Finance: There are Indications of Violation of the RSM Auditor. Accessed July 19, 2019: https://www.cnbcindonesia.com/market/20180830074647-17-30904/case-snpfinance-sri-mulyani- Hukum-deloitte-indonesia

Basudewa, D.G.A and Ni Kt, L.A.M. (2015). The Effect of Locus Of Control, Organizational Commitment, Auditor Performance, And Turnover Intention On Deviant Behavior In Audit. Udayana University Accounting E-Journal, 13(3), 944972.

Coram, P., Ng, J. and Woodliff, D. (2003) 'A survey of time budget pressure and reduced audit quality among Australian auditors', Australian Accounting Review, Vol. 13, No. 1, pp.38-45.

Dalton, T. and Kelley, T. (1997) 'A comparison of dysfunctional behaviours by tax accountants and auditors under time budget pressure', Advances in Accounting, Vol. 15, pp.193-208.

Dessler, G. (2000). Human Resource Management (8th Edition). Jakarta: PT. Prehallindo.

Donnelly, D. P., Quirin, J. J., \& O’Bryan, D. (2003). Auditor Acceptance of Dysfunctional Audit Behavior: An Explanatory Model Using Auditors' Personal Characteristics. Behavioral Research in Accounting, 15(1), 87-110. https: / / doi.org/10.2308/bria.2003.15.1.87

Donnelly, D. P., Quirin, J. J., \& O’Bryan, D. (2011). Attitudes Toward Dysfunctional Audit Behavior: The Effects Of Locus Of Control, Organizational Commitment, and Position. Journal of Applied Business Research (JABR), 19(1). https://doi.org/10.19030/jabr.v19i1.2151

Ghozali, I. (2016). Quantitative \& Qualitative Research Design for Accounting, Business, and Social Sciences. Semarang: Primary Yoga. 
International Journal of Environmental, Sustainability, and Social Sciences

ISSN 2720-9644 (print); ISSN 2721-0871 (online)

https://journalkeberlanjutan.com/index.php/ijesss

Gundry, L. (2006). Dysfunctional behaviour in the modern audit environment: The effect of time budget pressure and auditors' personality type on reduced audit quality practices. (October), 1-77.

Harini, D., Wahyudin, A., \& Anisykurlillah, I. (2010). Auditor Acceptance Analysis of Dysfunctional Audit Behavior: An Approach to Auditor Personal Characteristics. National Symposium on Accounting, 13, 1-28.

Harnoto. (2002). Human Resource Management (Second Edition). Jakarta: PT. Prehallindo.

Idrus, R., \& Chairunnisa, D. (2014). The Effect of Locus Of Control, Organizational Commitment, Auditor Performance, and Turnover Intention on Deviant Behavior in Auditing (Empirical Study on Public Accounting Firms in Pekanbaru and Padang). Online Journal of Students of the Faculty of Economics, University of Riau, 1(2), 116.

Indah, N., \& Boreel, S. (2016). Analysis of Factors Affecting Premature Dismissal of Audit Procedures (Empirical Study of KAP Auditors in East Java). 3, 226-235.

Indonesia, CNN. (2019, June 28). Ministry of Finance Revealed Three Mistakes of Garuda Indonesia Auditors. Accessed July 13, 2019: https: / /www.cnnindonesia.com/ekonomi/20190628124946-92-

407304/kemenkeu-beberkan-tiga-kelalaian-auditor-garuda-indonesia

Irawati, Y., and Mukhlasin, T. A. P. (2006). The Relationship of Auditor Personal Characteristics to the Acceptance of Behavioral Deviations in the Audit. National Accounting Symposium VIII Solo., 6(I), 1-13.

Kaptein, M. (2011) 'Understanding unethical behavior by unraveling ethical culture', Human Relations, Vol. 64, No. 6, pp.843-869.

Kelley, T. and Margheim, L. (1990) The impact of time budget pressure, personality and leadership variables on dysfunctional behaviour', Auditing: A Journal of Practice \& Theory, Vol. 9, No. 2, pp.21-41.

Luthans, F., \& Luthans, B. C. (2006). Organizational Behavior. North Carolina: Information Age Publishing.

Mangkunegara, \& Prabu, A. (2004). Human Resource Management. Bandung: Youth RSodakarya.

Martini, N. P. R., \& First, I. G. A. W. (2019). Auditor Dysfunctional Behavior: Impact of Auditor Competence, Machiavellian Nature, Time Pressure and Obedience Pressure (KAP Case Study in Bali). Economic Discourse (Journal of Economics, Business and Accounting), 18(1), 66-74.

Moorhead., \& Griffin. (2013). Organizational behavior. Jakarta: Four Salemba.

Muchlas., \& Makmuri. (2008). Organizational behavior. Yogyakarta: Gajah Mada University.

McGregor, C.C., Killough, L.N. and Brown, R.M. (1989) 'An investigation of organizational professional conflict in management accounting', Journal of Management Accounting Research, Vol. 1, pp.104-118.

Noe, R. A., \& Hollenbeck, J. R. (2014). Human Resource Management. Jakarta: Four Salemba.

Otley, D.T. and Pierce, B.J. (1996a) 'Audit time budget pressure: consequences and antecedents', Accounting, Auditing \& Accountability Journal, Vol. 9, No. 1, pp.3158.

Paino, H., Ismail, Z., \& Smith, M. (2010). Dysfunctional audit behavior: An exploratory study in Malaysia. Asian Review of Accounting, 18(2), 162-173. https: / / doi.org/10.1108/132173410159417

POB. (2000). The Panel on Audit Effectiveness: Reports and Recommendations. 20. 


\section{International Journal of Environmental, Sustainability, and Social Sciences \\ ISSN 2720-9644 (print); ISSN 2721-0871 (online) \\ https://journalkeberlanjutan.com/index.php/ijesss}

Pujaningrum, I. (2012). Analysis of the factors that influence the level of acceptance of auditors for behavioral deviations in auditing (empirical study at a public accounting firm in Semarang). Analysis of the factors that influence the level of acceptance of auditors for behavioral deviations in auditing (Empirical Study of Public Accounting Firms in Semarang), 1(1), 870-884.

Ratna Mappanyukki, (2017). The Role of the NonAssurance Service in Moderating the Effect Professional Ethict, Materality and Risk to Audit Quality Reduction.

Asmara, R.Y (2019). Determinants of audit Quality based on Auditor's Competence, Ethics and Independence: Emperical Study at Public Accounting Firms of West Jakarta and South Tanggerang pada tahun 2018.

Robbins, Stephen. P and Thimoty A. Judge. (2008). Organizational behavior. Jakarta: Four Salemba.

Robbins, Stephen. P and Thimoty A. Judge. 2017. Organizational Behavior. Jakarta: Four Salemba.

Soepriadi, S., Gunawan, H., \& Utomo, H. (2015). The Influence of Locus of Control, Self efficacy, and Professional commitment to Auditor Behavior in Audit Conflict Situations (Survey at Public Accounting Firms in Bandung, West Java). Journal of Accounting, 5(2), 361-367.

Suharyadi, \& S.K, P. (2016). Statistics for Modern Economics and Finance (3rd Edition). Jakarta: Four Salemba.

Svanberg, J., \& Öhman, P. (2016). The effects of time budget pressure, organisational-professional conflict, and organisational commitment on dysfunctional auditor behavior. International Journal of Accounting, Auditing and Performance Evaluation, 12(2), 131-150. https://doi.org/10.1504/IJAAPE.2016.075619

Shafer, W.E., Park, L.J. and Liao, W.M. (2002) 'Professionalism, organizationalprofessional conflict and work outcomes: a study of certified management accountants', Accounting, Auditing \& Accountability Journal, Vol. 15, No. 1, pp.46-68.

Svanberg, J. and Öhman, P. (2013) 'Auditors' time pressure: does ethical culture support audit quality?’, Managerial Auditing Journal, Vol. 28, No. 7, pp.572-591.

Treviño, L.K., Weaver, G.R. and Reynolds, S.J. (2006) 'Behavioral ethics in organizations:a review', Journal of Management, Vol. 32, No. 6, pp.951-90.

Willett, C. and Page, M. (1996) 'A survey of time budget pressure and irregular auditing practices among newly qualified UK chartered accountants', British Accounting Review, Vol. 28, No. 2, pp.101-120.

Wahyudi, Eko. (2013). The Influence of Locus of Control, Performance, Organizational Commitment, and Turnover Intention on Behavioral Deviations in Auditing (Empirical Study at a Public Accounting Firm in South Jakarta). Thesis. Syarif Hidayatullah State Islamic University.

Wahyuni, S. (2019). The effect of organizational commitment and locus of control on the behavior of reducing audit quality and auditor performance. Economics and Business (Riau Economics and Business Review, 10(4).

Wahyuni, S., \& Thurstone, L. (2017). The Effect of Multi-Dimensional Professional Commitment on Underreporting of Time Behavior (Empirical Study of Second Tiers Public Accounting Firms in Indonesia). 14(2). 